\title{
The Level of Knowledge and Skills of Teachers in Discipline Management
}

\author{
Steve Richard Nobes, Muhammad Hussin
}

To Link this Article: http://dx.doi.org/10.6007/IJARBSS/v11-i3/8961

DOI:10.6007/IJARBSS/v11-i3/8961

Received: 03 Febrary 2021, Revised: 28 Febrary 2021, Accepted: 09 March 2021

Published Online: 17 March 2021

\section{In-Text Citation: (Nobes \& Hussin, 2021)}

To Cite this Article: Nobes, S. R., \& Hussin, M. (2021). The Level of Knowledge and Skills of Teachers in Discipline Management. International Journal of Academic Research in Business and Social Sciences, 11(3), 498-510.

\section{Copyright: $\odot 2021$ The Author(s)}

Published by Human Resource Management Academic Research Society (www.hrmars.com)

This article is published under the Creative Commons Attribution (CC BY 4.0) license. Anyone may reproduce, distribute, translate and create derivative works of this article (for both commercial and non-commercial purposes), subject to full attribution to the original publication and authors. The full terms of this license may be seen at: http://creativecommons.org/licences/by/4.0/legalcode

Vol. 11, No. 3, 2021, Pg. 498 - 510

Full Terms \& Conditions of access and use can be found at http://hrmars.com/index.php/pages/detail/publication-ethics 


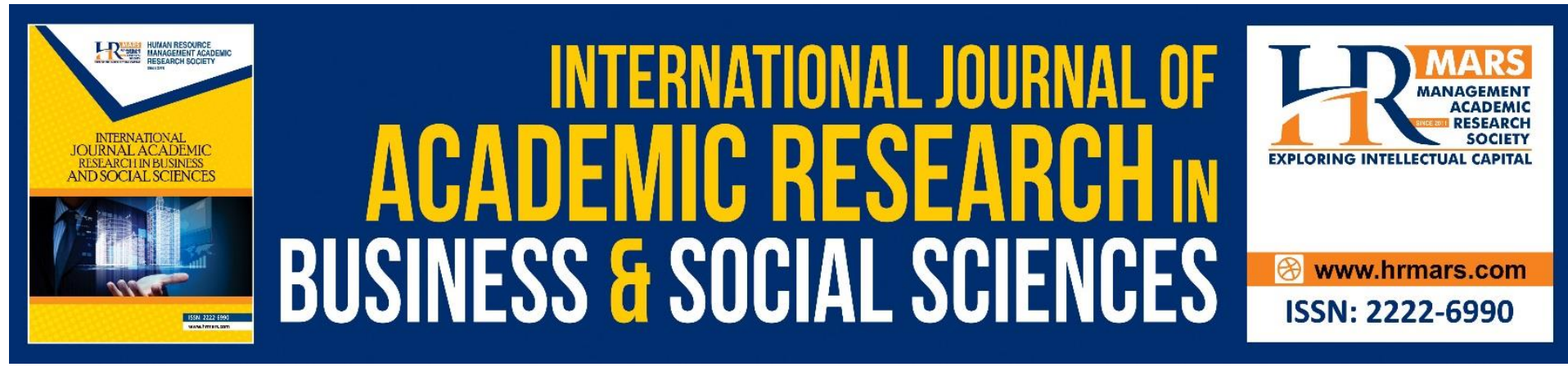

\title{
The Level of Knowledge and Skills of Teachers in Discipline Management
}

\author{
Steve Richard Nobes, Muhammad Hussin \\ Fakulti Pendidikan, Universiti Kebangsaan Malaysia, Bangi, Malaysia. \\ Email: steve_n1311@yahoo.com,muhsin@ukm.edu.my
}

\begin{abstract}
High self-discipline is capable of producing self-esteemed human capital. Schools are the place to build self-esteem among students as well as at home. This study was conducted to identify the level of knowledge and skills of teachers on student's discipline management in a primary school in Song district, Sarawak. The study also explores whether there is a difference in the level of management of student discipline based on demographic factors of the teacher. Therefore, we use exploratory case studies using holistic methods to focus on the two key aspects of identifying the level of knowledge and skills of teachers in disciplinary management. Accordingly, the interview approach was used to study 6 teachers to see the level of discipline management in the school. The findings have summarized the teacher's description of the level of disciplinary management in this school that is very high and proficient. In conclusion, this study explains that discipline management efficiency in schools can produce a balanced, physical, emotional, spiritual and intellectual human capital.
\end{abstract}

Keywords: Level of Knowledge, Skills, Discipline Management, Sarawak, Primary Schools

\section{Introduction}

The role of teachers is building a good personality for students through noble values in order to produce students who will be responsible in leading the community and the country in the future. The formation of student identity is important to create a Malaysian society that is skilled in terms of attitudes, behaviors, appearance and moral development of the students. Discipline is defined as the rules set to train a person to behave well and adhere to the rules set, but what happens to the student who still violates the rules that have been set. Students in schools need to be given attention so that they do not tend to be involved in the symptoms of discipline in school.

In schools, the headmaster is the head of the organization and the administrator who occupies the top hierarchy in school management. Thus, the headmaster is also responsible for the task of student management. In the context of student discipline, the task of the administrator is to find the causes of student misconduct and formulate suggestions or measures to prevent anti-disciplinary behavior in schools (Sidin, 1998). A study by Samad (1999), found that there are still weaknesses among principals in terms of their role in the management of discipline. 
Disciplinary management should be given a balanced emphasis just like other school management. According to Ismail (2006), the Ministry of Education proposes the establishment of a Student Affairs Advisory Committee at the district and school level (Ministry of Education, 1988). At the school level the committee consists of teachers only. This is important to the committee because it gets useful feedback to overcome disciplinary problems in schools, learn about students and give suggestions to improve the level of discipline in schools.

\section{Background of the Problem}

The efficiency of discipline management in schools is very important in dealing with disciplinary issues that arise in a planned manner and in accordance with the protocol or procedures set by the ministry. All teachers in the school are disciplined teachers and it is their responsibility to master and understand discipline management procedures. Students' disobedience to school rules is now a matter of concern. Therefore, efficient discipline management will be able to help the school to form the desired student personality. The school is responsible for clarifying the concept of discipline adopted in the school to form the students understanding of the effects and consequences of committing an offense.

In 2012, the highest cases of misconduct were recorded in criminal cases (Department of Statistics Malaysia, 2013). In the report, the involvement of primary school students recorded the highest percentage of 20.70 percent compared to secondary school students who recorded 10.66 percent. This involved a total of 5971 students which is 0.27 percent of the national enrolment. The percentage reported is very worrying for all parties because the implementation of discipline management at the primary school level has shown significant shortcomings. As such, the application of disciplinary values in schools is able to shape and transform an individual into human capital that gives value to the nation, religion and country. Teachers need to understand, master and be efficient in matters of discipline management in producing quality students not only physically and intellectually but also their emotions and personality.

\section{Statement of the Problem}

In the Malaysian Education Development Plan (PPPM) 2013 - 2025 (Ministry of Education, 2013), the government has allocated a total of 38.7 billion-ringgit to the Ministry of Education Malaysia in ensuring the national education policy is realized where a generation of skills in various aspects can be produced. This includes a generation that is physically, emotionally, spiritually and intellectually balanced. Desired student personality should be formed at a low level. Student personality shortcomings complicate the country's aspirations to produce skilled human capital difficult to achieve.

The teacher's job is not only to impart knowledge but also to apply high disciplinary values in students to have a noble attitude, values and morals. As such, a study on the level of discipline management among primary school teachers in Song District was conducted. This study was conducted to see the extent of knowledge and skills of teachers as discipline teachers so that effective discipline management can be practiced. A teacher's skills in dealing with student discipline problems are different. Competencies, abilities and skills refer to a person's behaviour. Teachers' competence in student disciplinary work should be seen as a whole. It does not just refer to the teacher's ability to question students, determine and confirm offenses or even carry out punishment only. On the other hand, it also requires a variety of other knowledge and skills such as the process of recording, evaluating, monitoring, 
interviewing parents, investigating, the concept of justice, making accurate decisions, planning prevention programs and nurturing values. Following the problems discussed, the researcher has chosen a primary school in Song district as the study respondents

\section{Research Objectives}

The objectives of this study are to: -

1. Identify the level of knowledge of primary school teachers in implementing student discipline management in Song District.

2. Identify the level of student discipline management skills among primary school teachers in Song District.

3. Identify whether there is a difference in the level of management of student discipline based on demographic factors such as the gender of the teacher.

4. Identify whether there are differences in the level of management of student discipline based on demographic factors that is the period of service as a teacher.

\section{Research Questions}

The study conducted tries to get answers to the questions posed as follows: -

1. What is the level of knowledge of primary school teachers in implementing student discipline management in Song District?

2. What is the level of student discipline management skills among primary school teachers in Song District?

3. Are there differences in the level of student discipline management according to demographic characteristic of gender?

4. Are there differences in the level of student discipline management according to the demographic characteristic of the period of service as a teacher?

\section{Conceptual Framework}

Teachers should have a solid knowledge of their duties as discipline teachers in schools. Student discipline management is a challenging task not only for school administrators but all teachers as the implementing team. Thus, a conceptual framework has been developed for the purpose of this study as shown in Figure 1 below.

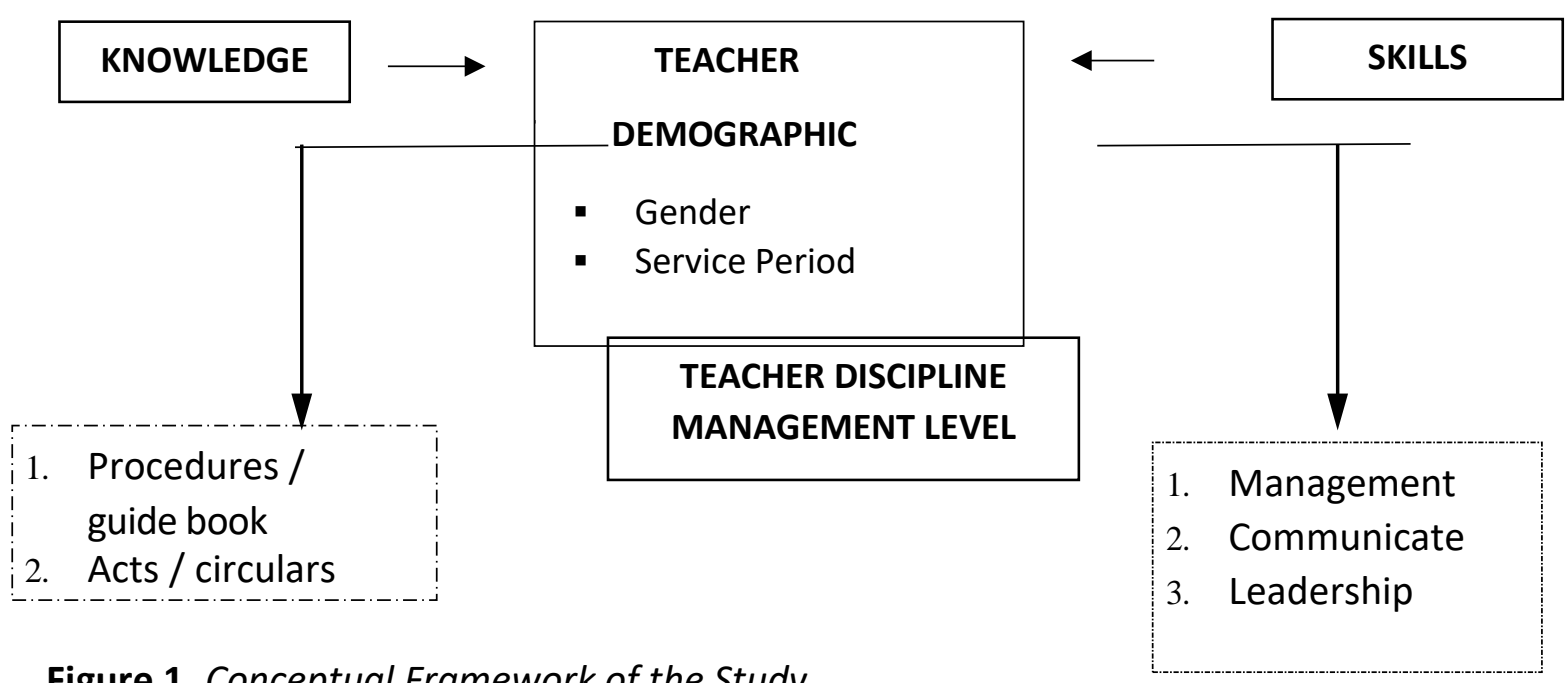

Figure 1. Conceptual Framework of the Study

Source: Adapted from Competency Model by Malek and Swee (2002) 
Figure 1 shows the level of discipline management competence among school teachers as measured through the knowledge and skills of teachers in discipline management in schools. Management level is the dependent variable for this study. In the management of student discipline in schools, the level of knowledge and skills of teachers as discipline teachers on the concepts and rules of discipline, procedures for managing student misconduct cases, the types of misconduct listed and how to communicate with students need be mastered by the teachers. Weaknesses in mastering student discipline management cause teachers to be less caring and less skilled when faced with the problem of disciplinary violations in schools. Independent variables consist of the demographic factors of teachers consisting of gender and duration of service as a teacher. Researchers would like to see if the above independent variables affect the level of competence of primary school teachers in disciplinary management in schools.

\section{Literature Studies \\ Discipline Concept}

According to Etzioni (1964) discipline refers to the process of controlling beings involving the following three aspects namely (a) coercive control based on the use of threats, (b) utilitarian form control based on material rewards, and (c) control symbolic form that focuses on prestige, esteem or social such as love and acceptance.

Furthermore, there are several researchers who define discipline as an educational process. For example, Kohlberg (1984) argues that children need help to understand the reasons for performing an action. In elaborating on that definition, Dewey (2009) argues that helping children means developing their interest in learning as a process of self-discipline formation.

According to Nor (2000), a discipline not only meant to have, appreciate and embrace the conduct expected by the public but also willing to accommodate treatments in a broader context, namely obedience and loyalty to the school, district, state and country. Ashaari (2001) defines discipline as the willingness of an individual to respect and abide by the law whether the discipline is imposed externally or voluntarily.

In the context of schools, the notion of discipline is often referred to by educators to the definition given by the Cabinet Committee Report examining the Implementation of Education Policy (1979) as: -

1. A person's willingness to respect and abide by the law;

2. Ability to work or do something in a fairly orderly manner;

3. Respect the rights of other individuals and do not interfere with the interests of others;

4. Practicing good behavior;

5. Practicing the spirit of helping each other;

6. Improve existing conditions through constructive efforts; and

7. Willing to serve the community

In conclusion, school discipline is a form of law or regulation that must be followed by all students to ensure that the school is in a conducive and safe state.

\section{Understanding in Terms of Concept}

Competence refers to the ability of managers and employees to perform all activities or work in the organization in the best way beyond what has been planned. This means that a manager must ensure that the organization can achieve maximum results by using minimal resources. 
Boyatzis (1982) states that the concept of competency is defined as 'Effective performance of a job is the pertainment of specific results (i.e., out comes) required by the job through specific action while maintaining or being consistent with policies, procedures, and condition of the organizational environment......'. In short, an individual's competence is influenced by his or her self-image, traits, intentions, social roles and attitudes. While in terms of the meaning of the concept of management, Akmaliah (2001) quotes Drucker writing that states that management is a social process that exists to obtain cooperation, participation and involvement among members to achieve organizational goals. In the aspect of discipline management, it refers to the activities of teachers who act as discipline teachers to perform their duties in planning, managing, directing, controlling resources efficiently and effectively in an effort to improve the disciplinary performance of students.

In this study, efficient disciplinary management should be guided by the procedures set by the MOE through professional circulars such as "Circular Letter No. 18/1988: Use of discretion when taking action that is;

"In exercising power, discretion, consideration and attention should be given to the accuracy of decision-making, in addition to being open, willing to listen to views and not be defensive. Negotiations should be done prudently, diplomatically and done in a harmonious atmosphere."

\section{Humanistic Model}

Humanistic models have been introduced by several psychologists such as Carls Rogers (19021987) and Abraham Maslow (1908-1970). This model has a positive view of human beings where it emphasizes that human beings have the power to determine their own behavior. Self-concept, growth, self-potential and satisfaction are emphasized in this model. Emotional disturbances will exist if an individual's potential does not develop or his needs cannot be met. A person's experience influences the individual's behavior where a positive and encouraging experience can form a brilliant personality and identity and thus provide an opportunity to develop one's potential towards goodness.

\section{Social Exchange Theory}

Social exchange theory can be defined as a learning that occurs by observing others doing something or making a person a model for behavior (Shoba, 2007). This means that the environment will influence student behavior.

\section{Discipline Management Problems}

The leadership aspect is seen as an important one in discipline management. According to Ramaiah (1992) a person who is involved in the leadership process either individually or a combination of several people then this situation is considered as a leadership process. Leadership is a process of individual potential and skills of mind, capacity, capability and wisdom to govern, direct, motivate and influence others. Among the teacher leadership styles that influence disciplinary work are the iron-clad teacher leadership approach, conflicts of interest, over-directing due to examination-oriented systems and community pressures.

The concept of discipline needs to be understood in depth, clearly, without hesitation, prejudice and looking at discipline from a holistic perspective. The concept of discipline is not intended to find fault with students and provide punishment alone. Instead, it demands the positive attitude of discipline teachers to apply various ideologies about discipline. For example, the concept of justice, building students' self-confidence in a system, educating 
personality, self-image and student loyalty to school. Disciplinary teachers have the opportunity to play their role in the concept of justice to students (Willis \& Rosen, 1977).

The approach to dealing with disciplinary problems is still an 'individual task' that takes place 'face to face' between a discipline teacher and students. The solution approach depends on the abilities of the individual. Assistance from others is only needed in the event of serious disciplinary cases (Mun, 2003). One way to help teachers overcome disciplinary problems is to establish cooperation by involving teachers in planning problem solving (Abon \& Pollastri, 2018). With this, teachers can discuss based on their knowledge and skills on problem solving methods. Therefore, the problem-solving approach can be implemented based on precise and effective measures.

Teachers 'knowledge and skills in these aspects will assist teachers' work in solving disciplinary related problems although it is acknowledged that none of the approaches can be considered the most appropriate, accurate and effective. However, teachers' knowledge and skills on discipline management by referring to the relevant behavioral theory models are an advantage in helping to improve the effectiveness of discipline management. This step can help teachers understand and solve disciplinary problems (Rohaty, 1999).

According to Mukhtar (2002), the factor of teacher expertise in mastering knowledge and meeting current developments is an important factor in ensuring the success and excellence of the school. In this regard, staff development programs in schools are seen to increase the level of individual competence. Teachers' involvement in discipline management becomes more effective if given exposure to knowledge related to discipline management. Among them are effective communication and problem-solving techniques that are indeed important and often used among discipline teachers while performing their duties.

\section{Methodology}

This study uses qualitative methods. In the context of this study, the researcher chose the type of case study as the study design. A total of 6 teachers out of 10 teachers were selected as respondents. In this case, the researcher conducted interviews with teachers involved with the management of discipline in schools. Informal interviews were also conducted with the school teachers involved to obtain the accuracy of the information and also for the purpose of cross-checking as proposed by Fraenkel and Wallen (2003).

The background of teachers as the discipline teacher of a school can affect the effectiveness of discipline management, especially the knowledge and skills they have. Table 1 shows the profiles of the teachers studied.

\section{Table 1}

Teacher Profile

\begin{tabular}{llllll}
\hline Teacher & Age & Gender & Job Grade & Teaching Experience (Years) Academic Qualification \\
\hline G1 & 42 & Male & DG42 & 13 & Degree \\
G2 & 29 & Female & DG41 & 5 & Degree \\
G3 & 26 & Male & DG41 & 3 & Degree \\
G4 & 32 & Male & DG41 & 2 & Degree \\
G5 & 29 & Female & DG41 & 5 & Degree \\
G6 & 29 & Female & DG41 & 5 & Degree \\
\hline
\end{tabular}

In this study, the researchers have defined the characteristics of the respondents or teachers involved as subjects who have different experiences between 1 year to over 10 year as trained 
teachers. This is because different time periods can determine the skills and knowledge of these teachers in the management of discipline in this school.

\section{Research Findings}

From the interviews conducted there are 3 themes to find out the level of knowledge and skills of teachers in discipline management in schools, namely the level of knowledge of teachers on the basic principles of discipline, the level of knowledge of teachers on discipline strengthening programs and finally the level of teachers' skills on discipline management strategies.

\section{Teachers' Level of Knowledge of the Basic Principles of Discipline}

Findings of teachers' level of knowledge of the basic principles of discipline in schools towards the philosophy and goals of managing discipline in school management are high.

"...l know. The goal is to ensure that all students are disciplined and less misbehaving."

(Source: G5)

Respondents also know that appropriate punishment is imposed on students is proportionate with the offense committed as well as imposing appropriate punishment on students who commit mild disciplinary misconduct such as giving warnings and advice.

"...placing students in the corner of the classroom for disturbing other friends."

(Source: G2)

"...as far as not completing school work and being noisy, I give warnings and advice. If serious such as the offense of stealing and injuring a friend, caning and counselling sessions are necessary."

(Source: G5)

"...students who like not completing school work. Often I will warn and give counselling sessions."

(Source: G6)

Some think all teachers are discipline teachers. However, there are still limitations for ordinary teachers in performing their duties as discipline teachers in schools entirely. Findings from the respondents show that all respondents know their limitations or limitation as regular teachers in carrying out their duties as discipline teachers. Most respondents stated they would refer a serious disciplinary problem to the HEM unit for action. They say ordinary teachers do not have the power to cane students.

"...physical punishment is not allowed and if the student commits an offense continuously, the teacher should refer the student to the school disciplinary board."

(Source: G2)

"...On critical and serious problems should be left to the discipline teacher. The limit of ordinary teachers is to question and investigate. Discipline teachers have the right to impose punishment and caning."

(Source: G5)

The study found that all the respondents stated that they had read and knew the circular related to discipline in school.

"...The circular does not allow teachers to impose punishment on students as listed by the MOE."

(Source: G2) 
"... . For example, a professional circular letter Bill. 7/2003 and professional circular letter bill 8/1983."

(Source: G6)

\section{Level of Teacher Knowledge of Discipline Enhancement Program}

Interviews with the study respondents have concluded that a teacher level of knowledge on the strengthening of discipline is also high. This is stated by several programs that have been implemented. Among the programs that have been implemented are hostel carnivals, motivational camps and school uniformed unit camps.

"...Among the activities implemented by the school are hostel carnivals, talks, annual sports, class competitions and hostels."

(Source: G1)

"...the on book zero discipline and silence is the most effective in school here so far.

(Source: G5)

Continuous monitoring of these troubled students should also able to increase the level of discipline of the students where they will be involved with charity work in school. According to the study respondents, this school also has disciplinary monitoring methods implemented. "...commonly used methods are supervision by teachers, wardens and Student Management Assistants (PPM). This method is very effective if all parties play their respective roles. (Source: G3). With the cooperation of all parties, disciplinary management problems in this school can be implemented effectively.

In dealing with student discipline problems, references to behavioral models can help increase knowledge of problematic student behaviors. The humanistic model has a positive view of human beings where it emphasizes that human beings have the power to determine their own behavior. The results show that all respondents have referred to and used humanistic behavior models.

"...I use the humanistic model."

(Source: G5)

"...through praise if the student no longer commits the same offense."

(Source: G6)

The study also found that continuous encouragement to students with problems can reduce student misconduct. The study respondents stated that the way they encourage students is by getting closer to students and making friends with them. Praise is also one of the encouragements towards changing the attitude of the student.

"...praise. Students are happy when praised and will remain good."

(Source: G2)

"...The usual encouragement I get is to eat and do activities with them."

(Source: G5)

\section{Level of Teacher Skills towards Disciplinary Management Strategies}

As a teacher, the problem of student discipline is difficult to predict. Respondents stated that problem solving skills quickly and effectively are very important and all study respondents are able to solve problems quickly and effectively. ".. problem solving measures depend on the seriousness of the disciplinary problem committed. Ideally, teachers should consult the administrator".

(Source: G3). 
"...I can solve the problem if the problem is a mild disciplinary case. Most of these problems can be solved effectively."

(Source: G4)

The findings of the study found that all respondents have an effective level of communication skills in solving disciplinary problems in schools. These effective communication skills are closely related to a teacher's experience serving in school. This shows that the longer the teacher serves the higher the level of communication skills and communication techniques to solve students' problems.

"...speak kindly and politely. Students will tend to express why they made mistakes." (Source: G1)

"... Effective communication skills can have a positive impact. In addition, it can nurture students to feel valued and loved."

(Source: G3)

"... communication skills can solve disciplinary problems. If all discipline teachers have good communication skills, disciplinary problems will be solved easily."

(Source: G5)

With effective communication the teacher can convey a message or advice to students so as not to make repeated mistakes.

Studies also examine the ability of respondents to influence others to change. In this study all respondents stated able to influence students to change for the better.

"... Teachers are role models for students. So, I will do my best to keep my behaviour in good condition."

(Source: G1)

"... The ability to influence others is based on role models. Where students can learn good character and can be practiced."

(Source: G3)

"... able because usually, no matter how mischievous the student is, they listen to the teacher. (Source: G5)

Every student misconduct needs to be handled well. The skill of making a careful assessment of the mistakes made by students and making decisions correctly and accurately must be in the teacher. The findings of this study show that all respondents have the skills to make assessments and make the right decisions in evaluating student mistakes.

“... Do not impose immediate punishment and first investigate student misconduct or see if there is a change in the student after being warned.

(Source: G2)

"... Decisions will be made based on joint decisions. Teachers cannot make decisions individually.

(Source: G3)

“... I will make a thorough assessment before sentencing.

(Source: G5)

The findings of the study show that the teachers in this school really apply good behaviour value in their students. "... always praises students who have positive behaviours. I will also reprimand students immediately if they make a mistake." (Source: G2)."... by always giving advice and holding commendable student awards." (Source: G5). "... can by showing good behaviour to students to serve as role models." (Source G6). The discipline management skills shown by the teachers in this school can be seen with the decrease in the rate of student 
discipline problems in the middle of this year based on my reference on the discipline record book available at the PKHEM office.

Ongoing follow-up actions in disciplinary management can help strengthen student discipline compliance rates. The findings of the study show that the respondents is very committed in taking follow-up action to ensure the level of student discipline at a controlled rate.

"... make sure students always comply with the rules set by the school. Make patrols in dormitories, classrooms and always remind students during assemblies.

(Source; G1)

"... student development will be monitored with the cooperation of all school staff."

(Source: G3)

"... use other interventions if the first intervention finds a dead end."

(Source: G4)

"... I will record every disciplinary problem and take follow-up action."

(Source: G5)

"... I usually give praise or encouragement to students who show good behaviour and make this student an example to their other friends."

(Source: G6)

\section{Discussion, Recommendations and Conclusion}

The findings show that there is no difference in terms of the level of knowledge and skill level of teachers either in terms of gender demographics or duration of service as a teacher. This shows that the level of discipline management of teachers in this school is very high.

The results of the study show that the study respondents have a high level of knowledge on both aspects of knowledge and skills. From the interviews that have been conducted, it was found that almost all the respondents know and are able to implement disciplinary management in the school well. This explains that teachers have high skills in disciplinary management.

Discipline management competencies are determined by the headmaster as the administrator and leader of the organization. One of the tasks of the administrator is to find the cause of the student misconduct problem and summarize the details obtained and suggest measures to prevent student misconduct (Sidin, 1998). It is difficult for headmasters to handle student discipline problems alone without the help of teachers. Teachers are a group that deals directly with student discipline. Ordinary teachers even if they are not discipline teachers should look at discipline management as a whole.

In this case teachers must have a high level of knowledge and skills on various matters related to discipline. These include accurate information on current disciplinary developments whether inside or outside the school grounds, guidelines for disciplinary implementation procedures, types of students involved in disciplinary problems, identifying the cause of disciplinary problems, having problem solving skills, communicating with parents effectively and having disciplinary strengthening programs.

In conclusion, the teacher's competence in managing student discipline in school has a strong relationship with the level of knowledge and skill level of the teacher. The study shows significant contribution on how teachers should handle discipline issues. The findings also prove the importance of self control abiity discipline model has a positive impact on human beings where it emphasizes that human beings have the power to determine its own 
behavior. Self-concept, growth, self-potential and satisfaction that are emphasized in this model proven to be signficant.

\section{Reference}

Abon, J. S., \& Pollastri, A. R. (2018). The School Discipline Fix: Changing Behavior Using the Collaborative Problem Solving Approach (1st ed.). New York: Norton \& Company Inc.

Akmaliah, Z. L. P. (2001). Perancangan strategik untuk memperkasakan sekolah. Kuala Lumpur: Pustaka Cipta Sendirian Berhad.

Ashaari, O. (1998). Peranan, Tugas dan Tanggungjawab Guru di Sekolah. Kuala Lumpur: Utusan Publication and Distributors Sdn. Bhd.

Boyatzis, R. E. (1982). The competent manager: a model for effective performance. London: Wiley.

Department of Statistics Malaysia. (2013). Kuala Lumpur: Percetakan Negara.

Dewey, J. (2009). Democracy and education: An introduction to the philosophy of education. New York: WLC Books.

Etzioni, A. (1964). Modern Organizations. Englewood Cliffs: Prentice Hall.

Fraenkel, J., \& Wallen, N. (2003). How to design and evaluate research in education (6th ed.). New York: McGraw Hill.

Kohlberg, L. (1984). Essays on Moral Development: Vol. II. The Psychology of Moral Development: The

Nature and Validity of Moral Stages. San Francisco: Harper \& Row.

Malek, M. Y. S., \& Swee, L. L. (2002). Model kompetensi dan perkhidmatan awam Malaysia. Pengurusan Awam, 1(2).

Ministry of Education. (1988). Panduan Tatacara Disiplin Sekolah Untuk Guru Besar dan Pengetua. Kuala Lumpur: Dewan Bahasa dan Pustaka.

Ministry of Education. (2013). Pelan Pembangunan Pendidikan Malaysia (PPPM) 2013 2025. Kementerian Pendidikan Malaysia, Putrajaya.

Mukhtar, A. R. (2002). Program latihan dalaman sekolah: Kajian di kalangan guru di tiga buah sekolah menengah di Daerah Jelebu, Negeri Sembilan. Latihan IImiah Fakulti Pendidikan, Universiti Kebangsaan Malaysia.

Mun, T. K. (2003). Keperluan latihan di kalangan guru disiplin. Satu kajian kes di Kawasan Ampang. Serdang: Universiti Pertanian Malaysia.

Nor, S. M. (2000). Keberkesanan sekolah: satu perspektif sosiologi. Serdang, Selangor: Universiti Putra Malaysia.

Othman, M. I. (2006). Undang-undang untuk Pengetua dan Guru Besar. Kuala Lumpur: PTS Professional Publishing Sdn. Bhd.

Ramaiah, A. (1992). Kepimpinan Pendidikan: Cabaran Masa Kini. IBS Buku Sdn Bhd.

Rohaty, M. M. (1999). Model-model teoritis disiplin. In M. M. Rohaty, T. S. M. Merah, F. Karim, \& A. J. Hassan (Eds.). Disiplin dalam Pendidikan (pp. 13-20). Kuala Lumpur: Nurin Enterprise.

Samad, A. A. (1999). Peranan dan penglibatan pengetua dalam mempertingkatkan disiplin pelajar di sekolah menengah FELDA Daerah Tampin Negeri Sembilan. (Unpublished master's thesis). Universiti Kebangsaan Malaysia.

Shoba, C. K. (2007). Faktor-faktor yang mempengaruhi kemerosotan disiplin di kalangan pelajar sekolah menengah di Johor. Skudai: Universiti Teknologi Malaysia.

Sidin, R. (1998). Pemikiran Dalam Pendidikan. Shah Alam: Penerbit Fajar Bakti Sdn.Bhd. 
INTERNATIONAL JOURNAL OF ACADEMIC RESEARCH IN BUSINESS AND SOCIAL SCIENCES

Vol. 11, No. 3, 2021, E-ISSN: 2222-6990 @ 2021 HRMARS

Willis, R. J., \& Rosen, S. (1977). Education and self-selection. Journal of Political Economy, $87(5), S 7-S 36$. 